А.А. Гайворонская

\title{
СОЦИОСИНЕРГЕТИЧЕСКИЙ ПОДХОД К МОДЕЛИ ЭТНИЧЕСКОГО ЭКСТРЕМИЗМА
}

\begin{abstract}
Аннотация. В статье предпринята попытка описания на основе социосинергетического подхода вероятностной модели этнического экстремизма. Изучение этнического экстремизма на основе сочиосинергетического подхода обусловлено разными причинами: первая группа причин обусловлена процессами, происходящими в обществе, государстве, вторая группа - это причины, обусловленные непосредственно многовариантностью характеристик, видов и форм данного феномена, а именно методы синергетики предназначены для изучения систем (явлений), состоящих из большого числа частей (видов, характеристик), компонентов или подсистем. В исследовании для описания синергетической модели этнического экстремизма мы использовали в качестве единиц анализа социальные представления, описывающие это явление.

Мы использовали следующие методы: ассоциативный метод, контент анализ и семантический диффреренциал с последующим построением семантических пространств Научная новизна состоит в описании на основе социосинергетического подхода вероятностной модели этнического экстремизма.

Выводы: представленная нами модель показывает сущностные характеристика данного феномена, а именно интолерантность, террор, догматизм и нигилизм представляют факторную структуру этнического экстремизма. Содержание данных факторов отражает субъективные, эмоционально-смысловые представления об этническом экстремизме и конечно, данные представления могут лишь отчасти моделировать это явление. Мы полагаем, что эта модель способна охарактеризовать этнический экстремизм при помощи определенных свойств, характерных для социосинергетических систем.
\end{abstract}

Ключевые слова: социосинергетическая модель, этнический экстремизм, социальные представления, интолерантность, террор, догматизм, нигилизм, семантические прораства, семантический диффреренциал, факторы.

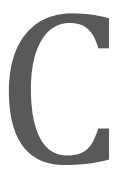

оциосинергетический поход отражает универсальные закономерности развития сложных динамических социальных систем, их изменения в условиях взаимодействия, а именно в контексте нашего исследования - структурные характеристики феномена этнического экстремизма. Существует большое количество теорий (теория катастроф Р. Тома, К. Зимана, теория диссипативных структур И.Р. Пригожина, теория детерминированного хаоса А. Пуанкаре, А.Н. Колмогорова) которые также выражают концепции и идеи теории самоорганизации. Синергетика - это наука, изучающая общие закономерности явлений и процессов в сложных неравновесных системах (например, социальнопсихологических и других) на основе присущих им принципов самоорганизации ${ }^{1}$. Методы синергетики междисциплинарны, полидисциплинарны и трансдисциплинарны. Это и объединение раз-

1 Синергетика (URL: http://http://ru.wikipedia.org/wiki/). личных научных теорий в объяснении какоголибо явления (междисциплинарность), участие одновременно нескольких разных научных теорий (полидисциплинарность) и перенос когнитивных схем и моделей из одной области в другую (трансдисциплинарность) ${ }^{2}$. Известно, что экстремизм как феномен представляет собой многовариантную систему, с разнообразными формами и характеристиками проявления. В разных исследованиях экстремизм рассматривается как социальный, политический, психологический феномен, имеющий тенденцию к саморазвитию ${ }^{3}$

\footnotetext{
Стёпин В.С. Саморазвивающиеся системы и постнеклассическая рациональность // Вопросы философии. 2003. № 8. C. 5-17.

3 Кухтевич Т.Н., Туманян О.В. Причины распространения этнического экстремизма и ксенофобии среди молодежи (Центральный федеральный округ): Сборник материалов социологического исследования / Под ред. проф. Л.Я. Дятченко. Белгород: Изд-во БелГУ, 2008. 326 с.
} 
Изучение этнического экстремизма на основе социосинергетического подхода обусловлено разными причинами: первая группа причин обусловлена процессами, происходящими в обществе, государстве, вторая группа - это причины, обусловленные непосредственно полифоничностью характеристик, видов и форм данного феномена, а именно, методы синергетики предназначены для изучения систем (явлений), состоящих из большого числа частей (видов, характеристик), компонентов или подсистем. На наш взгляд, именно социосинергетический подход в социально - психологических исследованиях, в данном случае, к феномену этнического экстремизма, поможет рассмотреть вероятностную модель этого феномена и раскрыть факторное содержание его сущностных характеристик.

В основном этнический экстремизм в разных исследованиях рассматривается как форма межэтнических конфликтов. Например, П. Мисир полагает, что этнический экстремизм - это продвижение и защита интересов конкретных этнических групп. Он обусловлен стремлением личности идентифицировать себя с конкретной этнической группой. По мнению автора, этнический экстремизм содержит в себе этнические и расовые конфликты. Этнические конфликты связанны с культурой, религией, стилем одежды, продуктами питания, убеждениями, ценностями. Расовые конфликты возникают на основе физических характеристик личности, такие как, цвет кожи, разрез глаз ${ }^{4}$.

E.В. Реутов считает, что этнический экстремизм основывается на этнофобии, которая является частным случаем ксенофобии. Этнофобия - это страх и предубеждение, к конкретным этническим общностям, так и к некоторым сформированным в массовом сознании образам «чуждых» народов («кавказцев», «южан», «инородцев») ${ }^{5}$.

Этнический экстремизм также можно проанализировать с позиций теории социального доминирования Дж. Сиданиуса и Ф. Пратто (social

4 Misir, P., 1998. The Social Construction Of Race-Ethnic Conflict in Guyana (URL: http://www.uog.edu.gy/files/ documents/prochancellor/The_Social_Construction_of_RaceEthnic_Confilct.pdf).

5 Реутов Е.В. Причины распространения экстремизма и ксенофобии в молодежной среде Причины распространения этнического экстремизма и ксенофобии среди молодежи (Центральный федеральный округ): Сборник материалов социологического исследования / Под ред. проф. Л.Я. Дятченко. Белгород: Изд-во БелГУ, 2008. С. 18. dominance theory, SDT) ${ }^{6}$. В этой теории рассматриваются этнические взаимоотношения в виде групповых иерархий. Социальное положение в группе, достижение высоких социальных позиций зависит от этнического происхождения или принадлежности к конкретной религии. Конфликт, неравенство в этих отношениях способствует этническому экстремизму. Этнический экстремизм проявляется в международных и межгосударственных отношениях, на федеральном и региональном уровнях.

Синергетика, представляя как линейный, так и нелинейный характер развития процессов и равновесных состояний, выделяет непредсказуемость поведения изучаемых систем их неустойчивость развития. В своем исследовании В.Ф. Петренко и O.В. Митина применяли синергетические модели для исследования динамики политического менталитета. В качестве единиц анализа рассматривались политические установки людей ${ }^{7}$. В нашем исследовании для описания синергетической модели этнического экстремизма мы использовали в качестве единиц анализа социальные представления, описывающие это явление.

Социальные представления - это особая форма обыденного коллективного знания, выражающая отношение к социальной действительности, являются особой формой обыденного коллективного знания, усваиваемые отдельным субъектом. Социальные представления могут иметь разное внутреннее обоснование, и могут определяться либо возникшей ситуацией, либо на основе сознательно используемых личностью ценностей.

Социальные представления, являясь основной характеристикой общественного и индивидуального сознания, оказывают влияние на поведение личности, на построение жизненных стратегий, связаны с самоопределением идентичностью ${ }^{8}$.

В нашем исследовании мы опирались на положения социально-психологической концепции

6 Pratto, Felicia; Stallworth, Lisa M.; Sidanius, Jim; Siers, Bret (1997). "The gender gap in occupational role attainment: A social dominance approach". Journal of Personality and Social Psychology 72 (1): 37-53.

7 Митина О.В., Петренко В.П. Синергетическая модель динамики политического сознания // Синергетика и психология. Тексты. Выпуск 1. Методологические вопросы. М., 1999.

8 Абульханова К.А. Российский менталитет: кросскультурный и типологические подходы // Российский менталитет: вопросы психологической теории и практики. М.: Ин-т психологии РАН, 1997. С. 7-37. 


\section{Этнос и этничность}

социальных представлений, разработанной французской психологической школой (С. Московиси, Ж.-К. Абрик, Д. Жоделе, и др.). Например, С. Московиси полагал, что социальные представления это ведущая характеристика и общественного и индивидуального сознания.

Изучение социальных представлений связано с анализом культурных форм выражения групп, организаций и трансформаций этого выражения9. Анализируя феномен социальных представлений, Д. Жоделе рассматривала их как специфическую форму знания, связывающую субъект с объектом. Акт представления понимался как акт мышления, позволяющий субъекту приблизиться к объекту ${ }^{10}$. Ж.-К. Абрик, рассуждая о природе социальных представлений, считал, что они помогают осмысливать реальность в системе личностных отношений, а также способствуют адаптации. Социальное представление имеет свою структуру: ядро и периферический строй. Ядро связано со смыслом объекта представления, отношением к нему, периферическая система объясняет значение ядра, образуя семантическое поле представления, отражая его вариативность ${ }^{11}$.

В отечественной психологии социальные представления рассматривались на основе субъектноличностного подхода и концепции социального мышления (К.А. Абульханова, М.И. Воловикова, И.А. Джидарьян, Т.П. Емельянова, И.Б. Бовина). В частности, К.А. Абульханова отмечала, что социальные представления являются одной из процедур социального мышления и чтобы стать принятыми, требуют усилий личности, другие представления могут блокироваться, третьи - усваиваются автоматически, представления могут быть либо умозрительными абстракциями, либо выражать позицию, либо становятся основанием, опорой для личности. Механизмами формирования и закрепления социальных представлений выступают категоризация, интерпретация, то есть трансформация информационных когнитивных элементов в «репрезента-

9 Moscovici, S. (2001) Why a theory of social representations? // Representations of the social: bridging theoretical traditions / Eds. by K. Deaux, G. Philogène. Oxford: Blackwell Publishers. P. 18-61.

10 Jodelet, D. (1984) Les représentations sociales. P.: Presses Universitaires de France.

11 Abric, J-C. (2001) A Structural Approach to Social Representations // Representations of the Social: Bridging Theoretical Traditions / Eds. by K. Deaux, G. Philogène. Oxford: Blackwell Publishers. P. 42-47. тивно-образные», способствуя формированию социальной (групповой) идентичности ${ }^{12}$. Согласно Т.П. Емельяновой социальные представления в условиях социальной нестабильности, поддерживает эмоциональное состояние индивидов и групп ${ }^{13}$.

Основные компоненты структуры социальных представлений - это знание о представляемом явлении, семантическое поле описываемого явления и отношение респондентов к данному явлению. Механизмами формирования и закрепления социальных представлений выступают категоризация, интерпретация, то есть трансформация информационных когнитивных элементов в «репрезентативно-образные», способствуя формированию социальной (групповой) идентичности. Социальные представления, подвергаясь изменениям (флуктуациям) образуют из своих содержательных (аттракторов) структуру, которую можно представить в виде факторов представляемых модель этнического экстремизма. Конечно, эти факторы до определенного предела описывают саму систему, что может способствовать устойчивости предложенной структуры в течение определенного времени. При превышении флуктуирующими параметрами критических значений (изменения общественно политической ситуации) наступает момент, когда изменение этих параметров может привести к скачкообразному переходу просто представлений в качественно иное состояние, на новую траекторию развития, например - установки. Так наступает точка бифуркации - точка ветвления вариантов развития. Таким образом, в изменяющихся условиях эволюция системы представлений является последовательностью различных аттракторов, переход между которыми происходит через неустойчивые состояния.

Цель данного исследования - это описание вероятностной модели этнического экстремизма и раскрытие факторного содержание характеристик.

\section{Методы исследования.}

Описание вероятностной модели этнического экстремизма предполагало реализацию качественно-количественного анализа данных.

\footnotetext{
12 Абульханова К.А. Социальное мышление личности. Современная психология: состояние и перспективы исследований. Ч. 3. Социальные представления и мышление личности. М.: ИПРАН, 2002. С. 88-103.

13 Емельянова Т.П. Социальное представление - понятие и концепция: итоги последнего десятилетия // Психологический журнал. 2001. Т. 22. № 6. С. 39-47.
} 
Исследование проходило в два этапа: на первом этапе для изучения социальных представлений об этническом экстремизме мы использовали ассоциативную методику. Обработка проводилась при помощи контент анализа (выделение смысловых единиц, общий подсчет социальных представлений). Выбор смысловых единиц (социальных представлений) для анализа осуществлялся в соответствии с задачей исследования, оптимально отражая смысл этнического экстремизма.

На втором этапе исследования мы изучали структуру содержания социальных представлений об экстремизме, используя психосемантический метод семантического дифференциала, с построением семантических пространств.

Метод семантического дифференциала направлен на изучение идентификаций, при изменении эмоционального отношения к явлению, в нашем случае этническому экстремизму. Семантические пространства, представляя собой операциональную модель сознания, использовались нами для описания факторной структуры социальных представлений об экстремизме. Различные признаки данного феномена выступали координатными осями многомерного семантического пространства, где социальные представления - это точки в этом пространстве, при этом значения признаков этих объектов - это координаты или проекции точек на оси, а различия между социальными представлениями - это расстояния между точками. Полученные координаты образовывают выделенные в факторном анализе ортогональные факторы: «Оценка», «Сила» и «Активность», по выраженности которых происходит сравнение семантического поля объекта у разных групп ${ }^{14}$. После заполнения полученные матрицы подвергались процедуре факторизации. Все статистические расчеты проводились с помощью компьютерных программ: Excel 2007 и программы Statistica 6.0.

В исследовании приняло участие 242 человека, в возрасте от 17 до 35 лет, средний возраст молодых людей $M=24,9$ лет, стандартное отклонение $\mathrm{SD}=1,79$, женского пола 152 человека.

Все испытуемые были отобраны на основе рандомизированного отбора, постоянно проживающие в городе Смоленске и Смоленской области, в городе Екатеринбурге и в городе Ростов на Дону. Это были учащиеся колледжей, обучающиеся раз-

14 Петренко В.Ф. Основы психосемантики: учебное пособие для студ. вузов. 2-е изд., доп. СПб.: Питер, 2005. личным специальностям, студенты различных вузов, работающая молодежь. Женщины и мужчины были представлены равномерно (количественные различия статистически не значимы). В состав выборки вошли представители разных национальностей (русские, татары, белорусы, аварцы, чеченцы, кабардинцы и ингуши), они были представлены в равной степени (количественные различия статистически не значимы).

Описание и анализ результатов исследования.

Контент-анализ протоколов ассоциативного исследования позволил выделить более 1104 дескрипторов (социальных представлений характерных для этнического экстремизма). В среднем на каждый протокол приходилось около 3,5 дескрипторов. Были отказы от участия в исследовании 7\%.

Ведущие темы в описании феномена этнического экстремизма были следующие:

а) насилие, жестокость против тех, кто принадлежит к иной этнической группе;

б) освободительная борьба;

в) способ достижения власти.

В ходе обследования были получены следующие дескрипторы, описывающие социальные представления об этническом экстремизме.

Насилие, межэтнические конфликты, принижение национального достоинства, неуверенность в завтрашнем дне, национальное возрождение, нетерпимость к представителям иных наций, глобализация, социальные барьеры, национализм, освободительная борьба, антисемитизм, радикальные методы, погромы, национальные противоречия, конфликты, антиобщественная направленность, противоправные деяния, изменения общественных отношений, неонацизм, взгляды, основанные на презрении к местному населению, агрессивное утверждение своих групповых интересов любой ценой, идеи сепаратизма, инциденты, национальные традищии, презрение к труду, гордость, готовность к преступлению, пренебрежение к законам, расовая неполноценность, нестабильность общества, декларативность законов, бюрократизм и коррумпированность чиновников и др.

Испытуемым предъявили набор дескрипторов (социальных представлений), описывающих феномен этнического экстремизма. Была предложена следующая инструкция: Оцените, пожалуйста, в баллах насколько с Вашей точки зрения, то или иное определение может охарактеризовать этнический экстремизм, экстремистскую деятельность. Вам предлагается шкала оценок в диапазоне 7 бал- 


\section{Семантическое пространство 1 и 2 фактора}

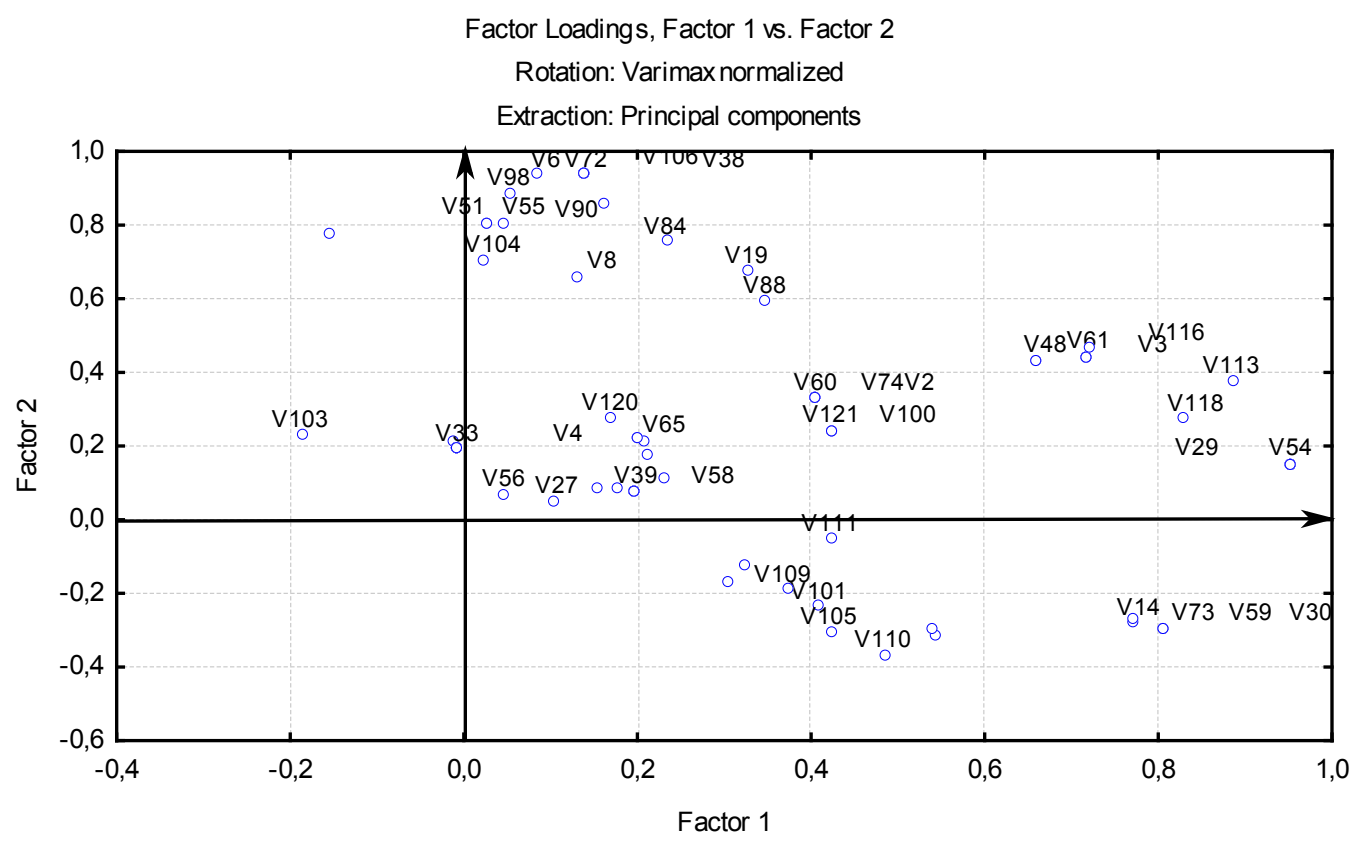

лов $(3 ; 2 ; 1 ; 0 ;-1 ;-2 ;-3)$, где оценка 3 соответствует максимальному согласию с утверждением. -3 , если утверждение обладает противоположной характеристикой. Оценка 0 ставится, если не подходит ни одна, ни другая характеристика. Укажите ваш: пол, возраст, национальность.

Описание и анализ результатов исследования.

Для факторного анализа пригодность имеющихся данных было подтверждена достаточным результатом теста Кайзера-Мейера-Олкина (КМО) (0.98) и значимым уровнем теста сферичности Бартлетта ( $<$ < 001). К матрице была применена процедура факторного анализа методом главных компонент с последующим поворотом факторных структур по принципу Varimax normalized

В результате было получено 5 факторов, объясняющих 91\% дисперсии, где для содержательного анализа было выбрано четыре значимых фактора. Рассмотрим веса этих факторов. Первый фактор объясняет 42\% дисперсии элементов (ведущий), второй фактор 23\% дисперсии, третий фактор 12\%, четвертый фактор 10\% дисперсии.

Первый фактор представляет собой классический фактор «силы» и был обозначен нами как фактор «интолерантность». Ведущие содержательные: нетерпимость к представителям иных наций $(0,95)$, неуравновешенность $(0,93)$, пренебре- жение к законам $(0,85)$, нехватка адреналина $(0,83)$, умеющий рисковать $(0,76)$. Ведущий конструкт в этом факторе нетерпимость показывает неприятие, стремление к подавлению, принижению или уничтожению, к отказу в праве на существование тому, кто придерживается иных взглядов и убеждений. Интолерантность - это неприятие культурных особенностей других национальностей и может проявляться как обычная невежливость (пренебрежение к законам, пренебрежение к правилам поведения), или более серьезных формах как «этноцентризм», «ксенофобия», «национализм», «культурный геноцид».

Второй фактор представляет фактор активности (действий), в который вошли шкалы - дескрипторы: «террор» $(0,93)$, «противоправные действия» $(0,88)$, «глобализация» $(0,79)$, «опасные заявления» $(0,75)$, «конфликты» $(0,72)$, «антиобщественная деятельность» $(0,68)$. Этот фактор мы обозначили как фактор «террор», потому что входящие в этот фактор шкалы дескрипторы связаны с устрашением, запугиванием. Причиной террора может быть борьба за распределение и перераспределение материальных и культурных ценностей. Агрессивные действия (конструкты: погромы, антисемитизм) создают образа врага как опасного, страшного, требования которого надо исполнять. 
Семантическое пространство 3 и 4 фактора

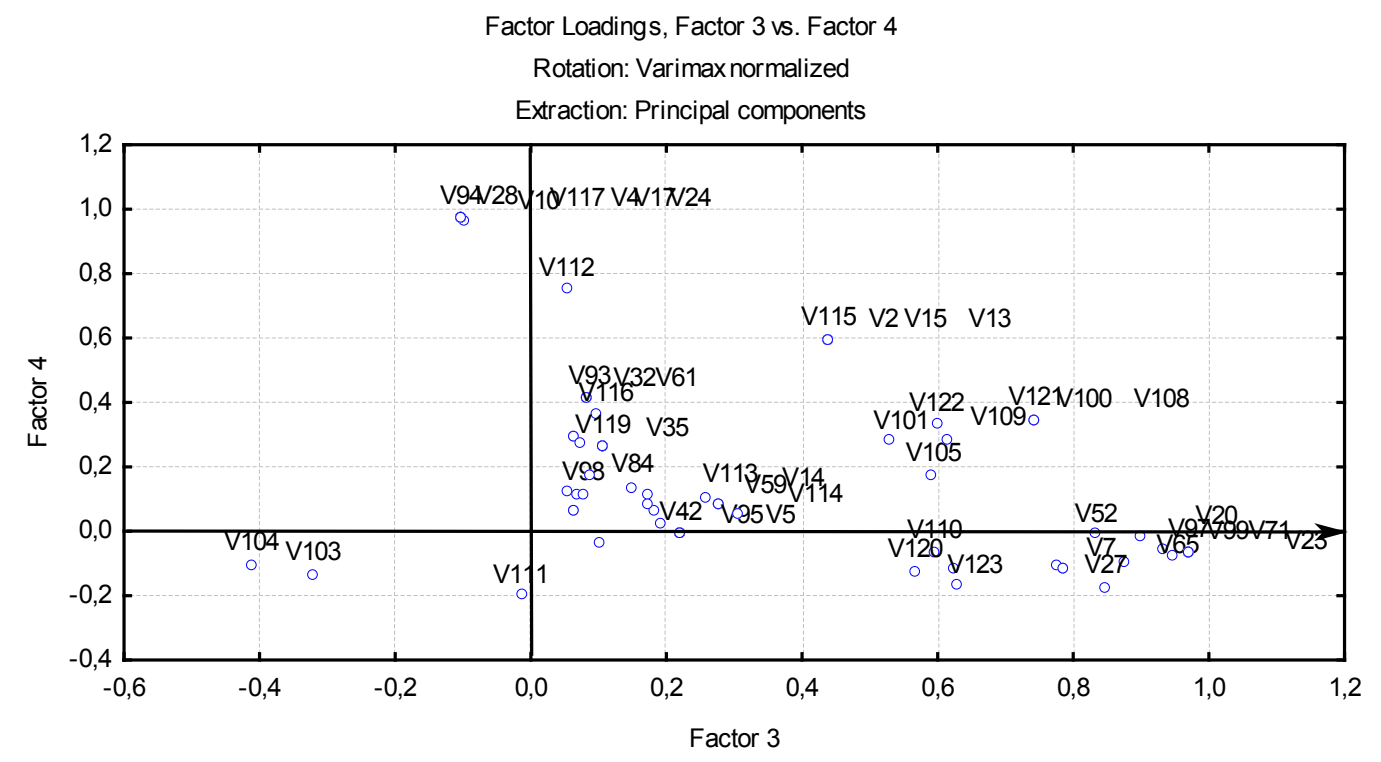

Семантическое пространство первого фактора открывают дескрипторы нетерпимость $\kappa$ представителям иных наций (v31), неуравновешенность (v54). Образуют склейку пренебрежение к законам (v 51), нехватка адреналина (v 56) и немножко дальше дескриптор умеющий рисковать (v 90). Категоричность взглядов, суждений свойственны интолерантным отношениям.

В семантическом пространстве второго фактора проявляется дескриптор «террор» ( $v 6)$, рядом с ним дескрипторы «провокация» (v72), «бандитизм» (v98). Оказались в склейке дескрипторы «глобализация» (v51), «противоправные действия (v55).

Третий фактор «оценка», включает в себя основные содержательные: «догматизм» $(0,97)$, «навязывание настроений» $(0,93)$, «отрицание переговоров» $(0,84)$, «идеи сепаратизма» $(0,79)$, «неуверенность в завтрашнем дне» $(0,68)$. Объединяющее значение по данному фактору - «догматизм». Этнический догматизм связан с коллективными традициями, передающимися из поколения в поколение. Они могут выступать как средство социализации в этой этнической группе и выражать групповое самосознание.

Четвертый фактор обозначен как фактор «нигилизм» отражает следующие шкалы: «декларативность законов» $(0,84)$, «митинги» $(0,78)$, «радикальные методы» $(0,72)$ «освободительная борьба» $(0,75)$, «бюрократизм и коррумпированность чиновников $(0,64)$ «национальное возрождение» $(0,52)$.
Семантическое пространство третьего фактора открывают дескрипторы догматизм (v71). Рядом с ним находятся дескрипторы навязывание настроений (v54). Образуют склейку идеи сепаратизма (v 52), неуверенность в завтрашнем дне (v 7.)

В семантическом пространстве четвертого фактора проявляется дескриптор «декларативность законов» (v94), рядом с ним дескрипторы «митинги» (v10), «подстрекательство» (v28). Оказались в склейке дескрипторы «бюрократизм» (v51), «коррумпированность (v55).

В результате проведенного исследования была получена вероятностная модель на основе социосинергетического подхода этнического экстремизма.

Таким образом, социосинергетическая модель этнического экстремизма показывает нам характеристики данного феномена, а именно интолерантность, террор, догматизм, нигилизм представляют сущность этнического экстремизма. Содержание данных факторов отражает субъективные, эмоционально-смысловые представления об этническом экстремизме и конечно, данные представления могут лишь отчасти моделировать это явление. Мы полагаем, что эта модель способна охарактеризовать этнический экстремизм при помощи определенных свойств, характерных для синергетических систем: незамкнутость (предпосылки и условия возникновения ксенофобии, этнофобии на основе интолерантных отношений), 


\section{Этнос и этничность}

диссипативность (спонтанные проявления), неустойчивость, иерархичность (зависимость от основного феномена), нелинейность (координация связей, отношений с другими проявлениями этого феномена).

Разрабатываемые в рамках синергетики понятийные и математические средства открывают для методологии новый формальный аппарат, позволяющий описывать феномен этнического экстремизма как частный случай комплексной динамической системы феномена экстремизма. Этнический экстремизм как явление определяется социально-групповыми особенностями общества, а формы его проявления связаны со спецификой социального поведения.

Данное исследование показывает, что совокупность социальных представлений образовывается под влиянием различных социально-психологических характеристик. Возможность моделирования

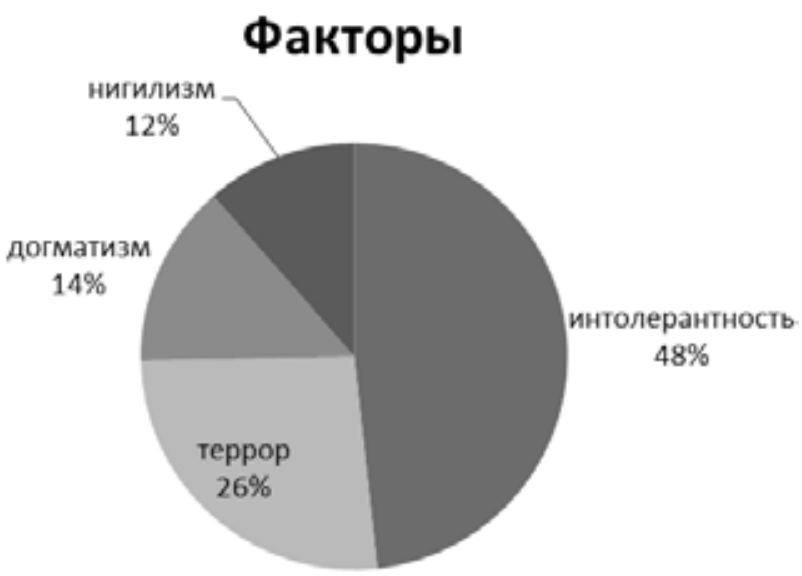

феномена этнического экстремизма, в терминах теории самоорганизации означает, что синергетическому описанию вполне доступно понимание и описание данного феномена.

\section{Список литературы:}

1. Абульханова К.А. Российский менталитет: кросс-культурный и типологические подходы // Российский менталитет: вопросы психологической теории и практики. М.: Изд-во «Ин-т психологии РАН», 1997. С. 7-37.

2. Абульханова К.А. Социальное мышление личности. Современная психология: состояние и перспективы исследований. Часть 3. Социальные представления и мышление личности. М.: ИПРАН, 2002. С. 88-103.

3. Васнецова А.С. Ваххабизм в России: характеристика, взаимосвязь с терроризмом и экстремизмом, перспективы государственного регулирования // NB: Проблемы общества и политики. 2013. № 11. C. 154-201. (URL: http://www.e-notabene.ru/pr/article_10185.html).

4. Васнецова А.С. Патриотическое воспитание граждан Российской Федерации в системе противодействия экстремистской и террористической деятельности: общефедеральные и региональные аспекты // NB: Национальная безопасность. 2013. № 5. C. 142-153. (URL: http://www.e-notabene.ru/nb/ article_9517.html).

5. Гайворонская А.А. Экстремизм как объект социально-психологического исследования // Психология и психотехника. 2012. № 1. С. 72-80.

6. Емельянова Т.П. Социальное представление - понятие и концепция: итоги последнего десятилетия // Психологический журнал. 2001. Т. 22. № 6. С. 39-47.

7. Кутырев B.A. Идейные причины современного терроризма в мире и России // NB: Проблемы общества и политики. 2012. № 3. C. 1-33. (URL: http://www.e-notabene.ru/pr/article_303.html).

8. Кухтевич Т.Н., Туманян О.В. Причины распространения этнического экстремизма и ксенофобии среди молодежи (Центральный федеральный округ): Сборник материалов социологического исследования / Под ред. проф. Л.Я. Дятченко. Белгород: Изд-во БелГУ, 2008. 326 с.

9. Митина О.В., Петренко В.П. Синергетическая модель динамики политического сознания // Синергетика и психология. Тексты. Выпуск 1. Методологические вопросы / Ред. И.Н. Трофимова, В.Г. Буданов. M., 1999.

10. Ноянзина О.Е., Гончарова Н.П., Максимова С.Г., Авдеева Г.С. Современные вызовы безопасности: оценка риска подверженности экстремистким и террористическим угрозам в условиях региональных социумов // NB: Национальная безопасность. 2012. № 1. С. 213-254. (URL: http://www.e-notabene.ru/nb/ article_92.html). 


\section{Психология и психотехника 3(66) • 2014}

11. Петренко В.Ф. Основы психосемантики: учебное пособие для студ. вузов. 2-е изд., доп. СПб.: Питер, 2005.

12. Реутов Е.В. Причины распространения экстремизма и ксенофобии в молодежной среде Причины распространения этнического экстремизма и ксенофобии среди молодежи (Центральный федеральный округ): Сборник материалов социологического исследования / Под ред. проф. Л.Я. Дятченко. Белгород: Изд-во БелГУ, 2008.

13. Седых Н.С. К вопросу о психологических последствиях терроризма // NB: Психология и психотехника. 2013. № 1. C. 101-130. (URL: http://www.e-notabene.ru/psp/article_229.html).

14. Седых H.C. Терроризм в контексте информационно-психологических угроз современности // NB: Национальная безопасность. 2012. № 1. C. 182-212. (URL: http://www.e-notabene.ru/nb/article_163. html).

15. Соснин В.А. Духовно-религиозные основы суицидального терроризма: идеология Глобального Джихада как психологическая мотивация оправдания суицидального терроризма исламскими радикалами // NB: Национальная безопасность. 2013. № 2. C. 112-159. (URL: http://www.e-notabene.ru/nb/ article_614.html).

16. Сочнев Д.В., Абасов М.М. Основные виды и наиболее распространенные формы международного терроризма // NB: Российское полицейское право. 2013. № 2. C. 91-108. (URL: http://www.e-notabene.ru/ pm/article_801.html).

17. Стёпин В.С. Саморазвивающиеся системы и постнеклассическая рациональность // Вопросы философии. 2003. № 8. С. 5-17.

18. Abric, J-C. (2001) A Structural Approach to Social Representations // Representations of the Social: Bridging Theoretical Traditions / Eds. by K. Deaux, G. Philogène. Oxford: Blackwell Publishers. P. 42-47.

19. Jodelet, D. (1984) Les représentations sociales. P.: Presses Universitaires de France.

20. Misir, P., 1998. The Social Construction Of Race-Ethnic Conflict in Guyana (URL: http://www.uog.edu.gy/files/ documents/prochancellor/The_Social_Construction_of_Race-Ethnic_Confilct.pdf).

21. Moscovici, S. (2001) Why a theory of social representations? // Representations of the social: bridging theoretical traditions / Eds. by K. Deaux, G. Philogène. Oxford: Blackwell Publishers. P. 18-61.

22. Pratto, Felicia; Stallworth, Lisa M.; Sidanius, Jim; Siers, Bret (1997). «The gender gap in occupational role attainment: A social dominance approach». Journal of Personality and Social Psychology 72 (1): 37-53.

\section{References (transliteration):}

1. Abul'khanova K.A. Sotsial'noe myshlenie lichnosti. Sovremennaya psikhologiya: sostoyanie i perspektivy issledovanii. Chast' 3. Sotsial'nye predstavleniya i myshlenie lichnosti. M.: IPRAN, 2002. S. 88-103.

2. Abul'khanova K.A. Rossiiskii mentalitet: kross-kul'turnyi i tipologicheskie podkhody // Rossiiskii mentalitet: voprosy psikhologicheskoi teorii i praktiki. M.: Izd-vo «In-t psikhologii RAN», 1997. S. 7-37.

3. Vasnetsova A.S. Vakhkhabizm v Rossii: kharakteristika, vzaimosvyaz' s terrorizmom i ekstremizmom, perspektivy gosudarstvennogo regulirovaniya // NB: Problemy obshchestva i politiki. 2013. № 11. S. 154-201. (URL: http://www.e-notabene.ru/pr/article_10185.html).

4. Vasnetsova A.S. Patrioticheskoe vospitanie grazhdan Rossiiskoi Federatsii v sisteme protivodeistviya ekstremistskoi i terroristicheskoi deyatel'nosti:obshchefederal'nye i regional'nye aspekty // NB: Natsional'naya bezopasnost'. 2013. № 5. S. 142-153. (URL: http://www.e-notabene.ru/nb/article_9517.html).

5. Gaivoronskaya A.A. Ekstremizm kak ob"ekt sotsial'no-psikhologicheskogo issledovaniya // Psikhologiya i psikhotekhnika. 2012. № 1. S. 72-80.

6. Emel'yanova T.P. Sotsial'noe predstavlenie - ponyatie i kontseptsiya: itogi poslednego desyatiletiya // Psikhologicheskii zhurnal. 2001. T. 22. № 6. S. 39-47.

7. Kutyrev V.A. Ideinye prichiny sovremennogo terrorizma v mire i Rossii // NB: Problemy obshchestva i politiki. 2012. № 3. S. 1-33. (URL: http://www.e-notabene.ru/pr/article_303.html).

8. Kukhtevich T.N., Tumanyan O.V. Prichiny rasprostraneniya etnicheskogo ekstremizma i ksenofobii sredi molodezhi (Tsentral'nyi federal'nyi okrug): Sbornik materialov sotsiologicheskogo issledovaniya / Pod red. prof.L.Ya. Dyatchenko. Belgorod: Izd-vo BelGU, 2008. 326 s. 


\section{Этнос и этничность}

9. Mitina O.V., Petrenko V.P. Sinergeticheskaya model' dinamiki politicheskogo soznaniya // Sinergetika i psikhologiya. Teksty. Vypusk 1. Metodologicheskie voprosy / Red. I.N. Trofimova, V.G. Budanov. M., 1999.

10. Noyanzina O.E., Goncharova N.P., Maksimova S.G., Avdeeva G.C. Sovremennye vyzovy bezopasnosti: otsenka riska podverzhennosti ekstremistkim i terroristicheskim ugrozam v usloviyakh regional'nykh sotsiumov // NB: Natsional'naya bezopasnost'. 2012. № 1. S. 213-254. (URL: http://www.e-notabene.ru/nb/article_92. html).

11. Petrenko V.F. Osnovy psikhosemantiki: uchebnoe posobie dlya stud. vuzov. 2-e izd., dop. SPb.: Piter, 2005.

12. Reutov E.V. Prichiny rasprostraneniya ekstremizma i ksenofobii v molodezhnoi srede Prichiny rasprostraneniya etnicheskogo ekstremizma i ksenofobii sredi molodezhi (Tsentral'nyi federal'nyi okrug): Sbornik materialov sotsiologicheskogo issledovaniya / Pod red. prof. L.Ya. Dyatchenko. Belgorod: Izd-vo BelGU, 2008.

13. Sedykh N.S. K voprosu o psikhologicheskikh posledstviyakh terrorizma // NB: Psikhologiya i psikhotekhnika. 2013. № 1. S. 101-130. (URL: http://www.e-notabene.ru/psp/article_229.html).

14. Sedykh N.S. Terrorizm $\mathrm{v}$ kontekste informatsionno-psikhologicheskikh ugroz sovremennosti // NB: Natsional'naya bezopasnost'. 2012. № 1. S. 182-212. (URL: http://www.e-notabene.ru/nb/article_163.html).

15. Sosnin V.A. Dukhovno-religioznye osnovy suitsidal'nogo terrorizma: ideologiya Global'nogo Dzhikhada kak psikhologicheskaya motivatsiya opravdaniya suitsidal'nogo terrorizma islamskimi radikalami // NB: Natsional'naya bezopasnost'. 2013. № 2. S. 112-159. (URL: http://www.e-notabene.ru/nb/article_614.html).

16. Sochnev D.V., Abasov M.M. Osnovnye vidy i naibolee rasprostranennye formy mezhdunarodnogo terrorizma // NB: Rossiiskoe politseiskoe pravo. 2013. № 2. S. 91-108. (URL: http://www.e-notabene.ru/pm/article_801. html).

17. Stepin V.S. Samorazvivayushchiesya sistemy i postneklassicheskaya ratsional'nost' // Voprosy filosofii. 2003. № 8. S. 5-17.

18. Abric, J-C. (2001) A Structural Approach to Social Representations // Representations of the Social: Bridging Theoretical Traditions / Eds. by K. Deaux, G. Philogène. Oxford: Blackwell Publishers. P. 42-47.

19. Jodelet, D. (1984) Les représentations sociales. P.: Presses Universitaires de France.

20. Misir, P., 1998. The Social Construction Of Race-Ethnic Conflict in Guyana (URL: http://www.uog.edu.gy/files/ documents/prochancellor/The_Social_Construction_of_Race-Ethnic_Confilct.pdf).

21. Moscovici, S. (2001) Why a theory of social representations? // Representations of the social: bridging theoretical traditions / Eds. by K. Deaux, G. Philogène. Oxford: Blackwell Publishers. P. 18-61.

22. Pratto, Felicia; Stallworth, Lisa M.; Sidanius, Jim; Siers, Bret (1997). «The gender gap in occupational role attainment: A social dominance approach». Journal of Personality and Social Psychology 72 (1): 37-53. 